\title{
Quality of water resources in Kullu Valley in Himachal Himalayas, India: perspective and prognosis
}

\author{
Nandini Thakur ${ }^{1} \cdot$ Madhuri Rishi $^{1} \cdot$ Diana A. Sharma ${ }^{1}$ (i) $\cdot$ Tirumalesh Keesari $^{2}$ (i)
}

Received: 27 October 2017 / Accepted: 3 January 2018 / Published online: 24 January 2018

(C) The Author(s) 2018. This article is an open access publication

\begin{abstract}
The water quality in mountain regions of Himalaya is considered to be good and quantity adequate. However, recent reports suggest that urbanisation and population growth have been tremendous, which are impacting the land use/cover changes and also endangering the water resources both in quality and quantity. This paper elaborates the systematic investigation carried out on different attributes impacting the drinking water resources in Kullu valley. Two approaches were employed in this study: (1) ex-ante approach involving field survey and secondary data analysis from ancillary sources and (2) hydrochemical approach for the measurement of water quality parameters from springs. Results from ex-ante approach infer rise in population of about 15\% during 2001-2011, which led to a significant change in land use pattern, microclimate and also increased water demand. Hydrochemistry of the water samples in the study area has indicated that the current status of spring waters is satisfactory for drinking purposes with a few incidences of high $\mathrm{NO}_{3}{ }^{-}$which is mostly attributed to contamination from sewage, while $\mathrm{F}^{-}, \mathrm{Cl}^{-}$and TDS contamination is mainly confined to hot springs. From both ex-ante approach and primary hydrochemical data it can be inferred that springs need to be restored in terms of both quantity and quality. Hydrochemical interpretation suggests two main groups of samples: (1) low TDS and $\mathrm{Ca}-\mathrm{Mg}-\mathrm{Cl}-\mathrm{HCO}_{3}$ type, which are mainly recharging waters with very less interaction with the aquifer material and (ii) moderate TDS and $\mathrm{Mg}-\mathrm{Ca}-\mathrm{Cl}, \mathrm{Ca}-\mathrm{Na}-\mathrm{HCO}_{3}, \mathrm{Na}-\mathrm{Ca}-$ $\mathrm{Cl}-\mathrm{SO}_{4}$ and $\mathrm{Ca}-\mathrm{Mg}-\mathrm{HCO}_{3}$ and have undergone water-rock interaction. Based on the inferences obtained from the Piper's, Chadha's and Durov's classification no evidence of hot springs contaminating or contributing to other cold springs and shallow groundwater (hand pump) is found. The study concludes that the water resources are vulnerable to anthropogenic interventions and needs treatment prior to drinking. Periodic monitoring of water quality and adopting proper treatment procedures are essential for supplying safe and sustainable water to the community in the Kullu valley, Himachal Pradesh.
\end{abstract}

Keywords Mountain habitant $\cdot$ Ex-ante approach $\cdot$ Hydrochemistry $\cdot$ Water quality $\cdot$ Urbanisation

\section{Introduction}

Availability of fresh water resources is quintessential for sustainable socioeconomic development throughout the world. Both surface water and groundwater contribute to domestic, industrial and agriculture needs in many countries. Millions of people lack access to safe drinking water and its scarcity is more acute in the arid and semi-arid regions (Dhar et al. 2014; Kumar et al. 2005; Keesari et al. 2002;

Tirumalesh Keesari

tirumal@barc.gov.in

1 Department of Environment Studies, Panjab University, Chandigarh 160014, India

2 Isotope and Radiation Application Division, Bhabha Atomic Research Centre, Trombay, Mumbai 400085, India
Lee and Han 2013). There are also reports on scarcity of potable water in mountainous regions of Himalayas (Singh and Kumar 1997; Shivanna et al. 2008). For fresh water supplies, groundwater in the form of springs has been the traditional and conventional source for the rural communities as well as for peri-urban and urban areas of Himalayan region of Indian subcontinent (Singh et al. 2014). In recent times, it is observed that drying up of springs is more frequent in Himalayan region and even the perennial springs show an alarming decrease in the discharges (Valdiya and Bhartiya 1991; Ravindranath et al. 2011; Tambe et al. 2011; Shivanna et al. 2008). Studies on springs have received limited attention in Himalaya though it falls under Global Biodiversity Hotspot (Tambe et al. 2011). With increased human intervention, drying of springs is becoming widespread across the Himalaya (Shivanna et al. 2008; Chinnasamy and 
Prathapar 2016) and especially in regions known for tourism (Boselli et al. 2005). Changes in land use pattern by both anthropogenic and natural factors during last two decades (1991-2011) have significantly impacted spring hydrology leading to a $35 \%$ decline in the river and stream flows in mountainous regions (Pant and Rawat 2015). In addition to quantity issues, the spring water quality was also reported to be declining due to anthropogenic factors and needs to be treated before using for domestic purposes (Nair et al. 2015). The infiltration of wastewater from cesspools and septic tanks into groundwater is considered as the major source of pollution (An and Breindenbach 2005; Al-Khashman 2007). Fertilizer application for agriculture and microbial contamination were also found to be impacting water quality of springs severely (Rowden et al. 2001). In addition to these factors, irrational land transformation also has disrupted the ecological balance of the Himalayan watersheds through reduced groundwater recharge, increased run-off and soil erosion (Tiwari 2000), which in turn adversely impacted the spring water hydrology.

Kullu district is one among the Himalayan regions facing acute shortage of water in the state of Himachal Pradesh of India, as the traditional water sources are either on the verge of extinction or have dried up (DDMP 2011). The water crisis has a significant and adverse impact on the overall economy of the district as well as living standards of the people (Vishwa et al. 2013). Low and erratic rainfall has led to drought conditions and the discharges of springs were reduced by about $10 \%$ in this district. This reduction in spring discharge has affected 332 habitations, 2 towns and 38,460 rural populations especially during summer season (Singh et al. 2010; DDMP 2011). Additionally the climate variability and hydrological extremes in this region have led water resources vulnerable and the ecosystem fragile (Nandy et al. 2015). Another factor impacting the natural resources is the rapid development of this region due to heavy tourism and inflow of migrants, which altered the biophysical setup of the Kullu valley in recent years (Vijay et al. 2016; Singh and Roy 2002). The available data with IPH (Department of Irrigation and Public Health, Kullu) indicate that among the various available water resources, drinking water supplies are mostly catered by springs in Kullu valley. In spite of the heavy dependency on the springs for drinking and potable needs there are no detailed studies on quality of the water resources particularly in upper Beas basin of Kullu district of Himachal Pradesh. This unavailability of the data on drinking water resources in this region constrains the water management authorities to plan a judicious and sustainable use of spring water for drinking as well as irrigation purpose.

Therefore, in this paper a comprehensive evaluation of the water resources especially spring water resources in Kullu valley is carried out involving Ex-ante approach and hydrochemical study. For the purpose of this study two major blocks have been selected which have envisaged highest degradation in spring water in terms of quantity and quality as well as very high tourism growth. The objectives of the paper are: (1) assessing the impact of urbanisation on water resources, (2) evaluate the current status of quality of spring water resources and (3) understand the hydrochemical evolution of water sources. This study forms a base for the future investigations in this region as well as other tourist hotspots of Himalayan states.

\section{Materials and methods}

\section{Study area description}

The study area forms a part of the Kullu district covering two blocks naming Naggar and Kullu (partially which lies in Beas Valley) with a total area of $1419 \mathrm{~km}^{2}$. The geographical coordinates lie between $31^{\circ} 50^{\prime}$ and $32^{\circ} 20^{\prime \prime}$ north latitudes and $76^{\circ} 50^{\prime}$ and $77^{\circ} 20^{\prime}$ east longitudes. The water sampling was carried from major springs located in the study area, available hand pumps and other sources such as STP (sewage treatment plant) outlet, water treatment plant outlet and hot springs. Water samples from very high altitude locations, barren and forest parts could not be collected, hence restricting the effective sampling area to be about $450 \mathrm{~km}^{2}$. The overall altitude of the study area varies from $1000 \mathrm{~m}$ to $6000 \mathrm{~m}$ amsl. The climate of the study area generally remains cool and dry. This region experiences three seasons in a year, (1) cold season (October to February), (2) hot season (March to June) and (3) rainy season (July to September). Snowfall generally occurs in December and January at higher elevations due to western disturbance which approaches India from the west (Singh and Roy 2002). The average annual rainfall of the district is $1405 \mathrm{~mm}$, out of which 57\% occurs during June to September (CGWB 2013). The study area and sampling sites are shown in Fig. 1.

\section{Geology and hydrogeology}

Geologically, a varied lithotectonic group exists in Kullu valley corridor comprising variety of rocks from Precambrian to Quaternary (Sah and Mazari 1998). The upper basin of river Beas locally termed as Rohtang Gneissic Complex constitutes gneisses, granites and magmatites of the Vaikrita Group. In the middle and gorge sections of the valley corridor, slates, garnetiferous schist, quartzite and limestone of the Jutogh Group dominate. Quaternary alluvial fans, fluvial terraces and relict periglacial slope deposits make up the shallow geological strata.

Hydrogeologically, the entire area of Kullu district can be divided into porous and fissured formations. Porous 


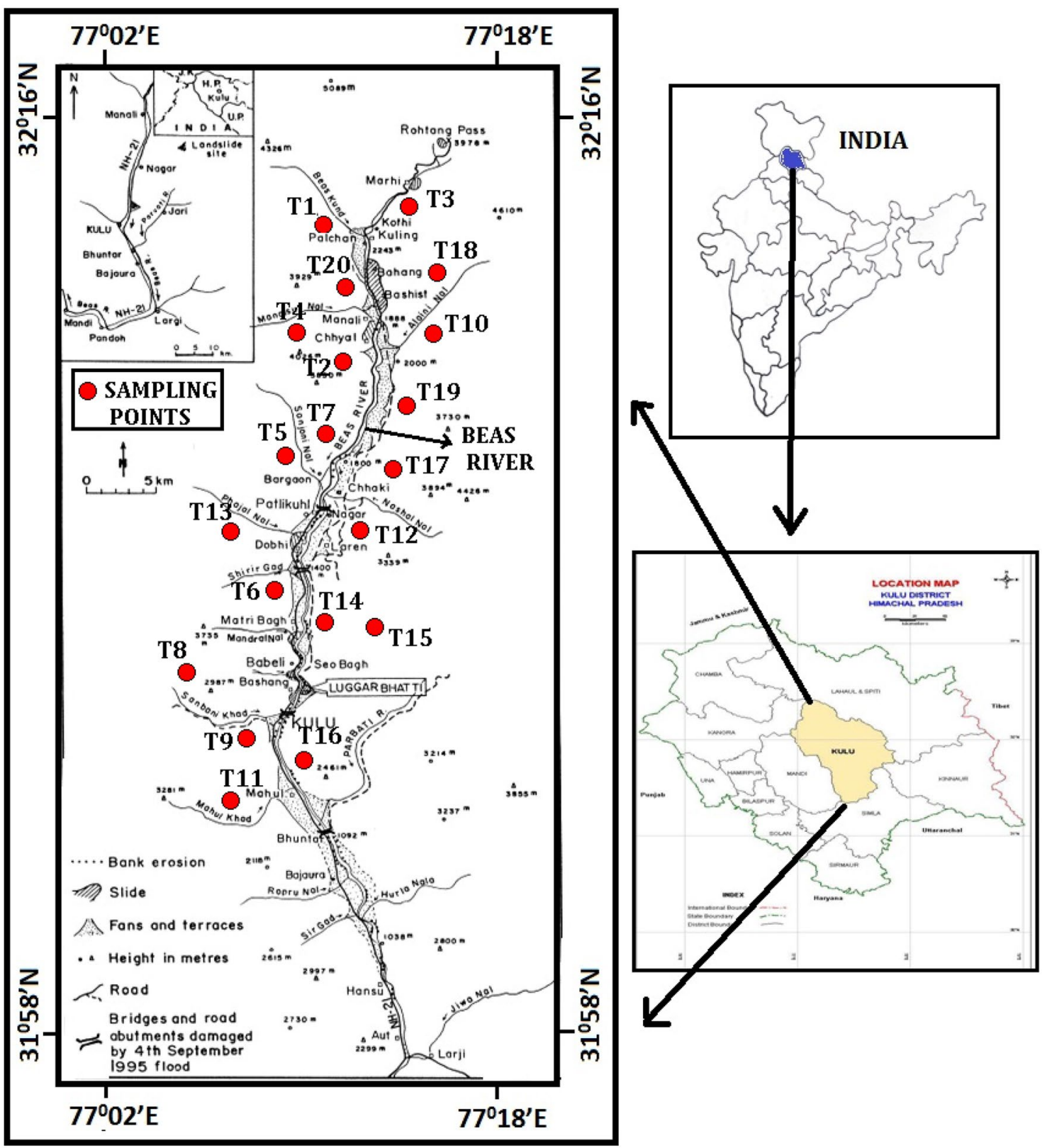

Fig. 1 Location map of the study area and sampling points

formation includes the unconsolidated sediments that are basically fluvial channel deposits, valley fill deposits, terrace deposits and alluvial fans. These sediments form the potential aquifers. Unconsolidated sediments underlie Kullu valley, Garsa valley, Manikaran valley, Lag valley and longitudinal valley all along the major rivers and khads. Fissured formation includes the semi-consolidated to consolidated sediments and are sedimentary, metamorphic and igneous in origin. This formation forms low to high hill ranges throughout the study area (Prasad et al. 2016). In Kullu valley, groundwater generally occurs under semi-confined to confined conditions. Phreatic aquifers are tapped mainly by open wells and constitute the major source of domestic and irrigation water supply in the valley area (CGWB 2013).

\section{Ex-ante approach}

An Ex-ante approach with reference to water resources is basically a means of forecasting that predicts the probability of incurring loss due to various natural and anthropogenic activities (Dolma et al. 2015; Helming et al. 2008). The Exante approach has been used in various hydro-ecological, biogeochemical and ecological functions (Brouwer et al. 1999); water quality (Desvousges et al. 1987; Carson and 
Mitchell 1993) and future impacts on water resources (Schltz and Lindsay 1990). Ex-ante approach helps in decoding the complexity associated with the study area in simple steps as shown by flow chart (Fig. 2). This approach employs secondary data, field survey and information from local residents. Information was also gathered from various commercial units such as hotels, resorts, cottages, lodges, and small scale eateries on water usage. This exercise was needed since these units are completely dependent on the spring water during peak tourist season. This enabled us to comprehend the importance of spring water towards better livelihood as well as economic development of this area. Data were also collected from different published and unpublished reports from various government and non-government institutions.

\section{Hydrochemical study}

The primary data were based on the hydrochemical study (field sampling) carried out during the year 2016 in which 20 samples were collected from different water resources particularly from major springs of the study area (Fig. 1). In addition to springs, other water bodies such as hot springs, STP outlets, hand pumps and water treatment plant samples were also sampled. The water samples were collected mainly along the Beas river spreading lower and upper reaches (Fig. 1). Elevation of the springs was between 1082 and $2321 \mathrm{~m}$ amsl (above mean sea level). Discharge of the springs varied from $60 \mathrm{lpm}$ (lire per minute) for a good

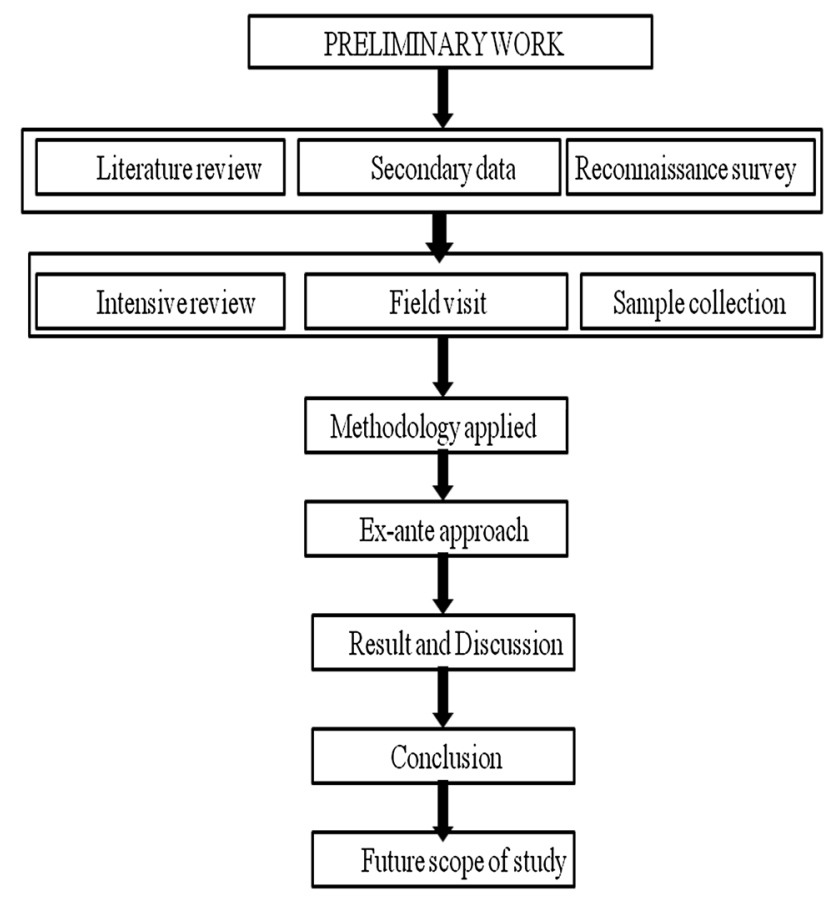

Fig. 2 Flowchart showing ex-ante approach during the preliminary investigation discharge spring to about $1 \mathrm{lpm}$ for a low discharge spring. Every village has at least one spring which is functional. But, most of the water supply is derived from springs located at higher elevation.

\section{Measurements}

The water samples were measured for physico-chemical parameters in situ using a water quality kit (Hanna Make). Daily calibration was carried out using suitable standard solutions and buffers. For calibrating electrical conductivity $1413 \mu \mathrm{S} / \mathrm{cm}$ calibration standard (HI7031M, Hanna Make) was used while for $\mathrm{pH}$ calibration three different standard buffers were used 4.01 (HI7004/1L, Hanna Make), 7.01(HI7007 M, Hanna Make) and 10.01 (HI7010L, Hanna Make). Sample water was collected from the running wells, active (flowing) springs or pumping out the water from the hand pumps to obtain the representative sample. For chemical measurements, $1 \mathrm{~L}$ of the water sample was filtered using $0.45 \mu \mathrm{m}$ cellulose acetate filter and stored in a polyethylene bottle, which is prewashed with distilled water. Major, minor and trace ionic species are $\left(\mathrm{Na}^{+}, \mathrm{K}^{+}, \mathrm{Ca}^{2+}, \mathrm{Mg}^{2+}, \mathrm{SO}_{4}{ }^{2-}\right.$, $\mathrm{Cl}^{-}, \mathrm{HCO}_{3}{ }^{-}, \mathrm{NO}_{3}{ }^{-}, \mathrm{Si}, \mathrm{PO}_{4}{ }^{3-}, \mathrm{F}^{-}$) were measured using standard methods (APHA 1998). For cation measurements, water samples were filtered and acidified using high pure $\mathrm{HNO}_{3}$ to $\mathrm{pH} 2$, while for anions only filtration was done. Statistical analysis MINITAB 16 and Microsoft excel were used.

\section{Result and discussions}

\section{Ex-ante approach}

\section{Population and tourism growth}

The population density of Kullu valley has increased from 28 to 69 persons $/ \mathrm{km}^{2}$ during 1961 to 2001, which is about $300 \%$ growth (Sah and Mazari 2007). In 2011, the population density has further increased to 80 persons $/ \mathrm{km}^{2}$. The population increase is estimated to be about $15 \%$. The decadal population growth of the study area from 1971 to 2011 is shown in Fig. 3a. A clear indication of increased growth rate can be observed from the plot (Fig. 3a). The population of the Kullu District in 1901 was 119,000 which rose to 437,903 in 2011 . The percentage of increase in population is found to be $25 \%$ during 1971 which increased to $26 \%$, 15\% during subsequent decades, 1991-2001, 2001-2011, respectively (Fig. 3a). The population rise is found to be higher in urban area. The population growth in urban region is $3.18 \%$ in 1961 which increased to $7.92 \%$ in 2001 and in 2011 it peaked at $9.47 \%$ (Fig. 3b). This growth is significantly higher considering the fact that other regions 

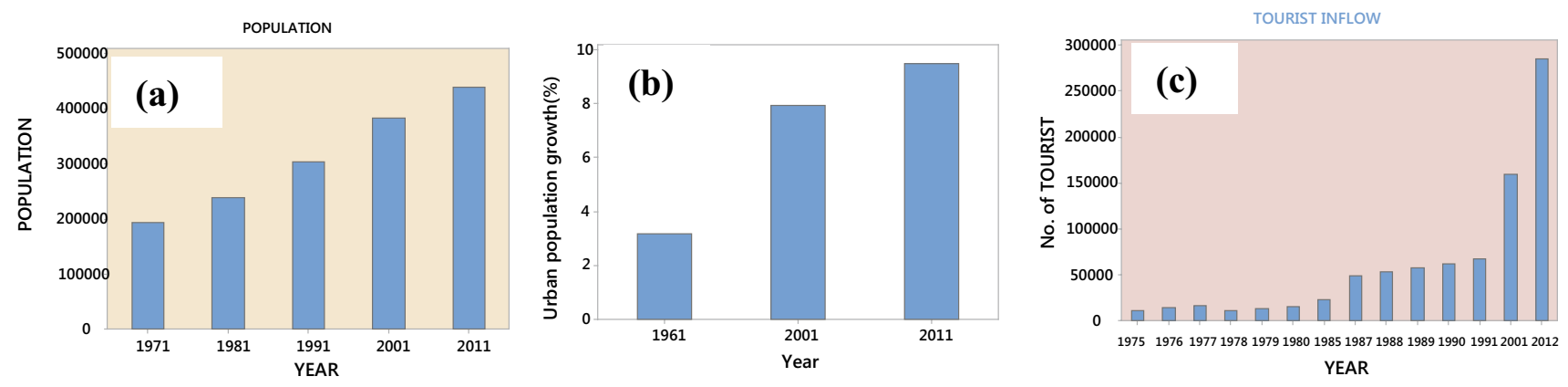

Fig. 3 a Decadal growth of population (source: Statistical abstract of Kullu 2014), b population growth in Urban area (source: Statistical abstract of Kullu 2014) and c tourist inflow rate in Kullu District, Himachal Pradesh (source: Department of Tourism 2017)

were also urbanised during the last one decade. The newly urbanised areas are Manali, Bhuntar and Banjar. The overall increase in population in Manali and Bhuntar areas in the year 2001 and 2011 is 157 and $43.3 \%$, respectively (Statistical abstract of Kullu 2014).

The study area is a tourist hot spot due to its scenic beauty, pleasant climate and easy approach. The total tourist inflow both foreign and domestic in 1975 was 11,062 which increased to 2,85,593 in 2012 as depicted in Fig. 3c. An upward trend in the tourist inflow was observed particularly from 1993 onwards. The data showed that the growth of foreign and Indian tourists increased by $1168 \%$ and 232\%, respectively, during 1993-2001 (Department of Tourism 2017). The tourist flow showed a slight decline during 1995-1996, which can be attributed to the natural calamities. A rise of about $80 \%$ in tourist growth was recorded during 1997. In general a steady growth of tourist inflow was recorded at $20 \%$ in Kullu valley as compared to total Himachal Pradesh during 1997-2001 (Sah and Mazari 2007).

The population rise, urbanisation and tourism have impacted the water resources, especially the groundwater in two ways: (1) reduction in area available for percolation of rainwater and (2) enhanced surface run off leading to reduced effective vertical recharge. These changes in land and subsequently in shallow zone groundwater affect spring discharges in both upstream and downstream locations resulting in decreased spring discharges and hardship to the residents.

\section{Changes in land use patterns}

Conversions of agricultural land to non-agricultural land and forest land to non-forest land are some of the important factors influencing the spring hydrology in the catchment areas. The total forest area in 1980-1981 was 4.9 lakh hectares, which reduced to 4.2 lakhs hectares in 2000-2001, indicating a decline in the forest area of about $14 \%$. A comparison of the land use data of 1994-1995 with 2000-2001 indicate that the barren and non-agricultural land decreased to about $6 \%$ and land for non-agricultural uses increased to about $8 \%$ in 2000-2001 (Sah and Mazari 2007). This clearly demonstrates the impact of increased urbanisation in the Kullu valley. A depletion in water level of shallow aquifer is also reported in this district which was attributed to increased exploitation of the groundwater to augment growing needs of the population (Rachna Bhatti 2016).

In addition to changes in land use, analysis of the rainfall data for the last 20 years (from 1995 to 2014) infers high long term fluctuations in the annual rainfall (IMD 2017). During the years 2001-2009 there was a deficit of rainfall while during 2010-2014 there is an excess of rainfall compared to the average value of $1081 \mathrm{~mm}$ (calculated for years 2001-2014). Report by Mishra and Nadda (2014) on the presence of total coliform and faecal coliform levels are indicative of presence of untreated or partially treated sewage in water supplies. It is noticed that untreated sewage from residential colonies/markets flows into the nearby water bodies and deteriorates the water quality.

\section{Hydrochemical study}

\section{Water quality assessment}

The hydrochemical data of the collected samples is given in Table 1 and the summary in Table 2. The accuracy of the chemical ion data was checked using charge balance error (CBE). The equation is given as below (Hounslow 1995):

$\mathrm{CBE}(\%)=\frac{\text { meq }(\text { cations })-\text { meq }(\text { anions })}{\text { meq }(\text { cations })+\text { meq }(\text { anions })} \times 100$.

The CBE of the water samples ranges from -4.7 to $5 \%$ and is within the acceptable limit of $\pm 5 \%$. The accuracy of the measurements was also confirmed by plotting anion equivalents versus cation equivalents (Fig. 4). Data fall along the line with slope 1 indicating that there is no discrepancy between the cation and anion amounts. Also, TDS

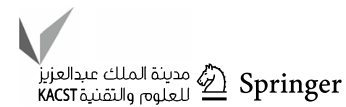




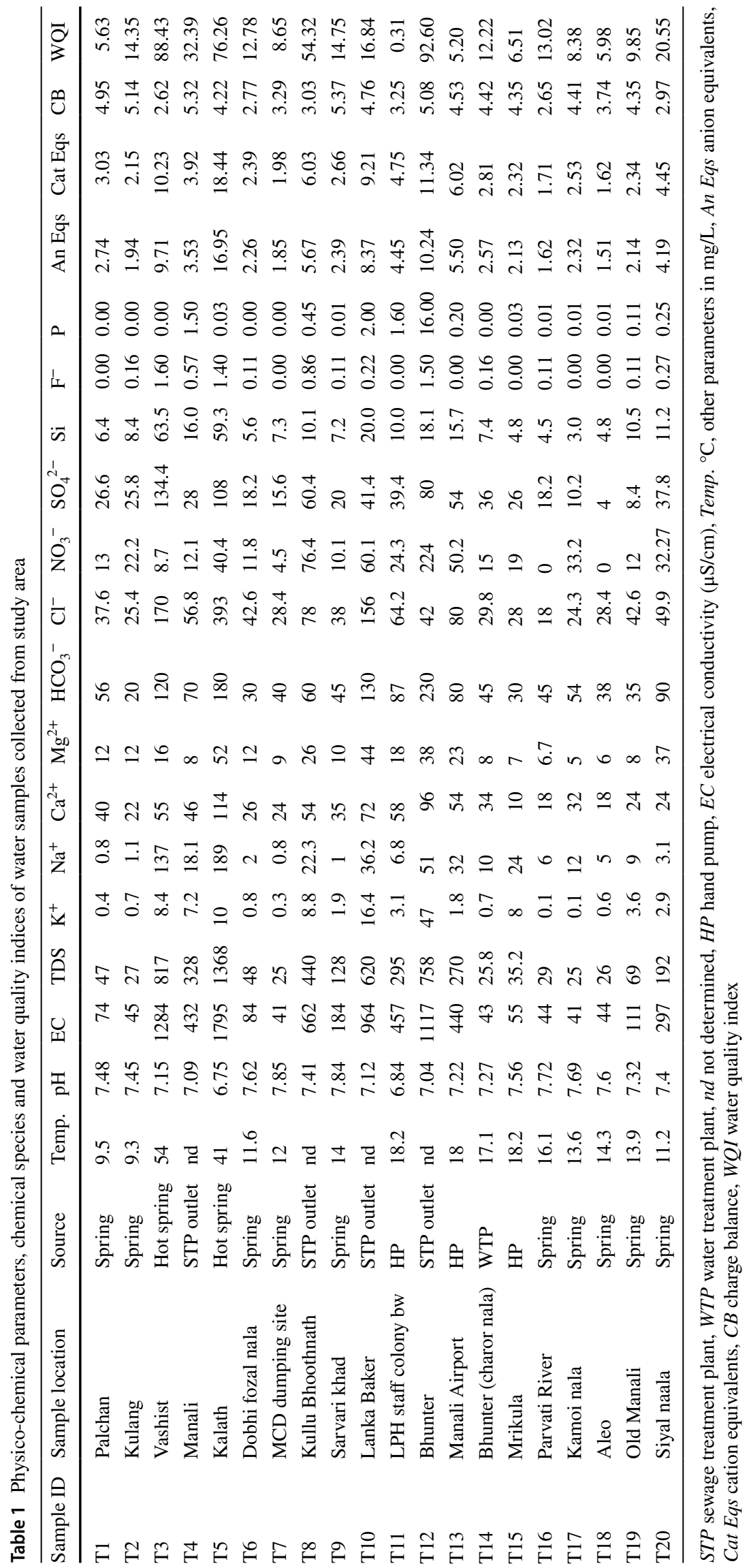


Table 2 Statistical summary of the hydrochemical parameters of water in the study area

\begin{tabular}{lllccc}
\hline S. no. & Parameter & \multicolumn{2}{l}{ Range } & Mean & Median \\
\cline { 3 - 4 } & & Min. & Max. & & \\
\hline 1. & $\mathrm{pH}$ & 6.5 & 7.85 & 7.4 & 7.4 \\
2. & $\mathrm{EC}$ & 41 & 1795 & 411 & 147 \\
3. & $\mathrm{TDS}$ & 25 & 1368 & 279 & 99 \\
4. & $\mathrm{Ca}^{2+}$ & 10 & 114 & 42.8 & 34.5 \\
5. & $\mathrm{Mg}^{2+}$ & 5 & 52 & 17.8 & 12 \\
6. & $\mathrm{Na}^{+}$ & 0.8 & 189 & 28.3 & 9.5 \\
7. & $\mathrm{K}^{+}$ & 0.1 & 47 & 6.14 & 2.4 \\
8. & $\mathrm{Cl}^{-}$ & 18 & 393 & 71.7 & 43 \\
9. & $\mathrm{HCO}_{3}{ }^{-}$ & 20 & 230 & 74.3 & 55 \\
10. & $\mathrm{NO}_{3}{ }^{-}$ & 0 & 224 & 33.5 & 17 \\
11. & $\mathrm{SO}_{4}{ }^{2-}$ & 4 & 134 & 39.6 & 27.3 \\
12. & $\mathrm{F}^{-}$ & 0 & 1.6 & 0.4 & 0.11 \\
13. & $\mathrm{WQI}^{-}$ & 0.3 & 92.6 & 24.9 & 12.9 \\
\hline
\end{tabular}

$E C$ electrical conductivity in $\mu \mathrm{S} / \mathrm{cm}, T D S$ total dissolved salts and all the values are in $\mathrm{mg} / \mathrm{L}$ except $\mathrm{pH}$, Min minimum, Max maximum, Med median

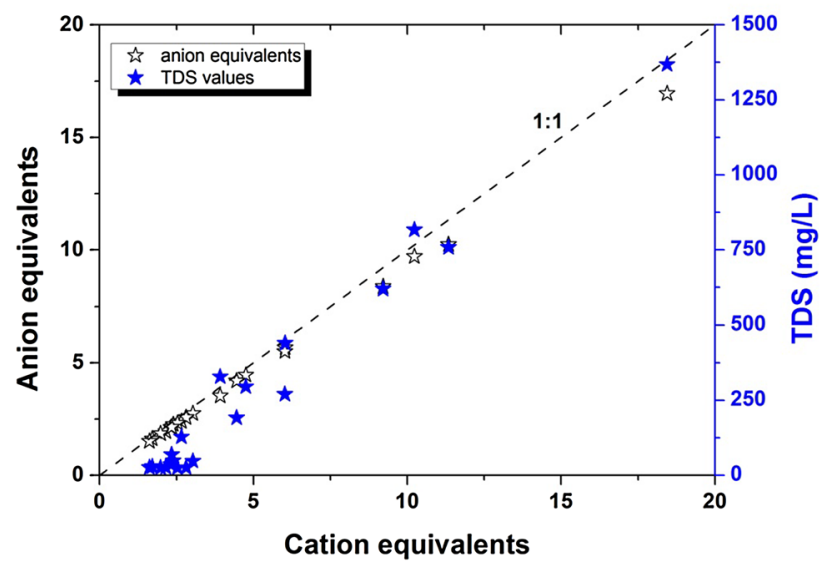

Fig. 4 Scatter plot of cation equivalents versus corresponding anion equivalents and TDS values of the water samples. The dashed line represents equimolar concentration

was plotted against cation equivalents and proportionality is expected between these two parameters. Figure 4 shows that the measured values match well with the TDS values of the water samples. Samples with lower TDS values fall slightly below the equimolar line. This could be due to slightly higher uncertainty in determining low concentrations of ions (especially close to detection limits), which is the commonly observed phenomenon in most of the analytical techniques.

The chemical data were checked for suitability for domestic purposes based on recommendations of WHO (2011). Temperature of the water samples ranges from 9.3 to $18.2^{\circ} \mathrm{C}$

(excluding hot spring samples) with a mean of $14.1^{\circ} \mathrm{C}$ indicating a wide spread in the data. Most of the high altitude springs show cooler temperatures close to $10{ }^{\circ} \mathrm{C}$ while low altitude springs and pumps show elevated temperatures of up to $18^{\circ} \mathrm{C}$. Hot spring samples show elevated temperatures up to $54^{\circ} \mathrm{C}$. $\mathrm{pH}$ of the samples range between 6.75 and 7.85 with a mean of 7.37 and a median of 7.40. Except one sample each from hot spring and hand pump rest of the samples show a neutral $\mathrm{pH}$.

Electrical conductivity (EC) is a measure of the total dissolved ions. Leaching and dissolution of the aquifer material as well as mixing of saline sources generally contribute to high EC in water (Hem 1991; Hounslow 1995). The EC ranges between 41 and $1117 \mu \mathrm{S} / \mathrm{cm}$ in the samples with a mean of $285 \mu \mathrm{S} / \mathrm{cm}$ and a median of $97 \mu \mathrm{S} / \mathrm{cm}$ (Table 2). The hot spring samples indicate very high EC up to $1795 \mu \mathrm{S} /$ $\mathrm{cm}$. It is found that spring samples normally show low EC $(<297 \mu \mathrm{S} / \mathrm{cm})$ while hand pump and other samples show higher EC values ( $>430 \mu \mathrm{S} / \mathrm{cm})$. A wide range of EC values in water samples is indicative of multiple sources of ions, such as atmospheric, geogenic and anthropogenic contamination (Keesari et al. 2002, 2016a; Sharma et al. 2016, 2017).

TDS (total dissolved solids) is estimated empirically from EC values as follows:

TDS $(m g / L)=0.67 \times$ Conductivity $(\mu \mathrm{S} / \mathrm{cm})$.

The TDS values range from 25 to $1368 \mathrm{mg} / \mathrm{L}$ and 1 out of 20 measured samples (5\%) show higher TDS levels compared to WHO (2011) permissible limit of $1000 \mathrm{mg} / \mathrm{L}$ (Table 2). These samples are collected from hot springs while rest of the spring, hand pump as well as other water sources showed TDS values within permissible limits.

Among major ions, calcium in the water samples ranges between 10 and $114 \mathrm{mg} / \mathrm{L}$ while magnesium ranges between

Table 3 Relative weight of chemical parameters for WQI

\begin{tabular}{|c|c|}
\hline Parameters & $\begin{array}{l}\text { Relative } \\
\text { weight } \\
\left(W_{i}\right)\end{array}$ \\
\hline EC & 0.0008 \\
\hline $\mathrm{pH}$ & 0.1415 \\
\hline TDS & 0.0012 \\
\hline $\mathrm{TH}$ & 0.0024 \\
\hline TA & 0.0020 \\
\hline $\mathrm{Ca}^{2+}$ & 0.0040 \\
\hline $\mathrm{Mg}^{2+}$ & 0.0120 \\
\hline $\mathrm{F}^{-}$ & 0.8023 \\
\hline $\mathrm{NO}_{3}^{-}$ & 0.0241 \\
\hline $\mathrm{SO}_{4}{ }^{2-}$ & 0.0048 \\
\hline $\mathrm{Cl}^{-}$ & 0.0048 \\
\hline$\Sigma W_{i}$ & 1.0000 \\
\hline
\end{tabular}


5 and $52 \mathrm{mg} / \mathrm{L}$ (Table 2). None of the samples exceeded the WHO (2011) limits for $\mathrm{Ca}^{2+}$ and $\mathrm{Mg}^{2+}$ concentrations (Table 3). The $\mathrm{Cl}^{-}$values range from 14.2 to $383 \mathrm{mg} / \mathrm{L}$ and 1 out of 20 samples (5\%) fall above WHO (2011) standard limit of $250 \mathrm{mg} / \mathrm{L}$ (Table 3). The high $\mathrm{Cl}^{-}$samples are mainly from hot springs. Consumption of water with high chloride might lead to health issues (McCarthy 2014). High levels of $\mathrm{NO}_{3}{ }^{-}$in potable water can lead to methaemoglobinemia (blue baby syndrome) in infants (Fan and Steinberg 1996) and gastric cancer and adversely effects nervous system and cardiovascular system (CPCB 2008). $\mathrm{NO}_{3}{ }^{-}$concentrations in water samples range between below detection limit and $224 \mathrm{mg} / \mathrm{L}$ (Table 2), and 4 out of 20 samples (20\%) exceed the WHO (2011) limit of $50 \mathrm{mg} / \mathrm{L}$ (Table 3). Samples with high concentration of $\mathrm{NO}_{3}{ }^{-}$represent domestic or decaying livestock wastes near the water source. Only 3 out of 20 samples (15\%) showed high F content which are mostly collected from hot springs and one from STP outlet point (Table 1). High $\mathrm{F}^{-}$in potable water results in mottling of teeth or fluorosis, both dental and skeletal (Ray et al. 1981; CPCB 2008; Brindha et al. 2011; Keesari et al. 2016b). Most of the samples in the study area showed $\mathrm{F}^{-}$concentration between below detection limit and $0.86 \mathrm{mg} / \mathrm{L}$ (Table 2) and are within the WHO (2011) permissible limit of $1.5 \mathrm{mg} / \mathrm{L}$. Water quality results indicate that the water quality is satisfactory for most of the ions except hot spring samples. The potential contaminant in the drinking water was found to be $\mathrm{NO}_{3}{ }^{-}$which is mostly derived from the man made activities.

\section{Water quality index (WQI)}

Water quality index (WQI) reflects the influence of combined water quality parameters on overall quality of water. It provides a useful indexing to represent the quality of the groundwater for drinking purpose to the consumers. WQI was calculated by adopted weighted arithmetical index method. Parameters considered for estimating WQI are; $\mathrm{pH}$, electrical conductivity ( $\mathrm{EC}$ in $\mu \mathrm{S} / \mathrm{cm}$ ), total dissolved solid (TDS in $\mathrm{mg} / \mathrm{L}$ ), total hardness (in $\mathrm{mg} \mathrm{CaCO}_{3} / \mathrm{L}$ ), total alkalinity (as $\left.\mathrm{CaCO}_{3}\right)(\mathrm{mg} / \mathrm{L}), \mathrm{Ca}^{2+}(\mathrm{mg} / \mathrm{L}), \mathrm{Mg}^{2+}(\mathrm{mg} / \mathrm{L})$, $\mathrm{Cl}^{-}(\mathrm{mg} / \mathrm{L}), \mathrm{F}^{-}(\mathrm{mg} / \mathrm{L}), \mathrm{SO}_{4}{ }^{2-}(\mathrm{mg} / \mathrm{L})$ and $\mathrm{NO}_{3}{ }^{-}(\mathrm{mg} / \mathrm{L})$. To calculate the WQI the WHO standards (WHO 2011) are used. The weighted arithmetic index method (Brown et al. 1970) has been used for the calculation. WQI is given by equation;

$q_{n}=100\left[V_{n}-V_{i 0}\right] /\left[S_{n}-V_{i 0}\right]$.

(Let there are $\mathrm{n}$ quality parameters considered and $q_{n}$ refers to the quality rating or sub-index of the $n$th parameter which reflects the contribution of the parameter towards the polluted water with respect to the standard value). $q_{n}=$ quality rating for the nth parameter of water quality, $V_{n}=$ estimated value of nth parameter at a particular sampling point, $S_{n}=$ standard permissible value of nth parameter, $V_{i 0}=$ ideal value of nth parameter in pure water (i.e. 0 for all other parameters except $\mathrm{pH}$ which has value 7).

WQI is calculated using this equation:

$\mathrm{WQI}=\frac{\Sigma q_{n} W_{n}}{\Sigma W_{n}}$,

where $W_{n}=$ unit weight of $n$th parameters, which is calculated by:

$W_{n}=K / S_{n}$,

$K=$ constant of proportionality and calculated as:

$K=\frac{1}{\Sigma\left(\frac{1}{S_{n}}\right)}$.

Table 3 describes the relative weights of chemical parameters for WQI calculation and the calculated water quality index for each sample is given in Table 1.

The WQI values range from 0.3 to 92.6 with an average value of 24.9 (Table 2). Table 4 describes the classification of water on the basis of WQI, according to the WQI values 16 out of 20 samples fall in excellent quality while rest of the samples vary from good to very poor quality.

\section{Hydrochemical evolution}

To understand the hydrochemical evolution of the spring water, hand pump and hot spring water, trilinear Piper's plot was constructed using the major ion data of the samples. The major chemical facies were found to be $\mathrm{Ca}-\mathrm{Mg}-\mathrm{Cl}-\mathrm{HCO}_{3}, \mathrm{Mg}-\mathrm{Ca}-\mathrm{Cl}, \mathrm{Ca}-\mathrm{Na}-\mathrm{HCO}_{3}$, $\mathrm{Na}-\mathrm{Ca}-\mathrm{Cl}-\mathrm{SO}_{4}$ and $\mathrm{Ca}-\mathrm{Mg}-\mathrm{HCO}_{3}$. Spring samples with low TDS show mainly $\mathrm{Ca}-\mathrm{Mg}-\mathrm{Cl}-\mathrm{HCO}_{3}$ and $\mathrm{Mg}-\mathrm{Ca}-\mathrm{HCO}_{3}$ while springs with relatively high TDS and hand pump samples showed mostly $\mathrm{Ca}-\mathrm{Na}-\mathrm{HCO}_{3}-\mathrm{Cl}$. Samples collected from hot spring samples are mainly $\mathrm{Na}-\mathrm{Ca}-\mathrm{Cl}-\mathrm{SO}_{4}$. From the diamond field of the trilinear plot, three main groups

Table 4 Classification of groundwater on the basis of water quality index (WQI)

\begin{tabular}{llc}
\hline WQI & $\begin{array}{l}\text { Classification of samples based on } \\
\text { WQI }\end{array}$ & $\begin{array}{l}\text { No. of } \\
\text { samples }\end{array}$ \\
\hline $0-25$ & Excellent water quality & 15 \\
$26-50$ & Good water quality & 2 \\
$51-75$ & Poor water quality & 1 \\
$76-100$ & Very poor water quality & 2 \\
$>100$ & Unsuitable for drinking & 0 \\
\hline
\end{tabular}




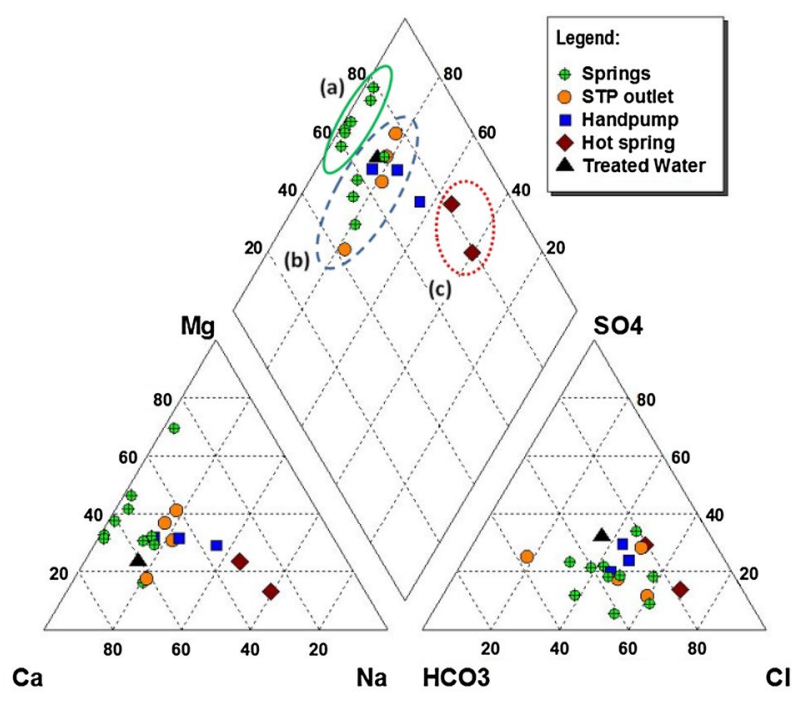

Fig. 5 Piper's trilinear plot water samples depicting the various hydrochemical facies

are discerned (Fig. 5). Group (a) samples are mainly spring water and represent more of recharging water with minimum interaction with the aquifer material. Group (b) samples are spring waters as well as hand pump, STP outlet and treated water (WTP). This group contains more TDS compared to group (a) samples and interaction with the aquifer material could have led to addition of the ions and thereby modification in the chemical facies. This also indicates that groundwater is relatively older compared to recharging waters of group (a). Group (c) represents hot spring water, which are $\mathrm{Na}-\mathrm{Ca}-\mathrm{Cl}$ type and are matured waters. These inferences indicate hot springs as such do not influence the local spring water quality in the study area (Table 5).

To further interpret the major ion data of the water samples, Chadha's plot was used. This plot helps in identifying the recharging water, processes of ion exchange, dissolution and base exchange in water samples (Sharma et al. 2016; Thilagavathi et al. 2012). This plot is constructed by calculating the difference in milliequivalent percentages of alkaline earths and alkali metals on the $X$-axis and weak acidic anions and strong acidic anions on the $Y$-axis. Chadha (1999) has divided this plot into four fields depending on the quadrant of their placement, and each of this field is assigned with a particular hydrochemical processes. field 1 represents $\mathrm{Ca}-\mathrm{HCO}_{3}$ type, mostly recharging waters, field 2 represents $\mathrm{Ca}-\mathrm{Mg}-\mathrm{Cl}$ type of reverse ion exchange waters, field 3 represents $\mathrm{Na}-\mathrm{Ca}-\mathrm{Cl}$ or $\mathrm{Na}-\mathrm{Cl}$ type of end member waters and field 4 represents $\mathrm{Na}-\mathrm{HCO}_{3}$ type of reverse ionexchange waters. Similar to the observations from Piper's plot, Chadda's classification also indicate a few spring samples falling in recharging field (field 1) while most of the spring and other water samples fall on the ion exchange category (field 2) as shown in Fig. 6. Samples from hot springs fall in the end member type of water (field 3 ). These waters generally create salinity problems and are unfit for both agriculture and drinking purposes (Chadda 1999).

Durov's diagram was used to further verify the geochemical processes occurring in the groundwater of the study area. This diagram is a composite plot consisting of two ternary diagrams where the cations of interest are plotted against the corresponding anions. The data are normalised to $100 \%$. This diagram is very useful in indicating the samples with similar chemical composition as well as determines a useful relationship among different water samples (Lloyd and Heathcoat 1985). The Durov plot of the water samples (Fig. 7) indicates that there are mainly two geochemical processes that could affect the genesis of groundwater in the study area.

Group (a) samples fall in field 5, based on Lloyd and Heathcoat (1985) classification, this trend can be attributed to fresh recent recharge water exhibiting simply dissolution or missing with no dominant cation or anion. Group (b) samples fall in field 8. This field indicates that

Table 5 Percentage of water samples exceeding WHO (2011) limits for drinking

\begin{tabular}{|c|c|c|c|}
\hline Parameter & WHO (2011) limits & $\begin{array}{l}\text { \% samples exceed- } \\
\text { ing limits }\end{array}$ & Undesirable effect produced beyond MPL (summarised from published reports) \\
\hline $\mathrm{pH}$ & $6.5-8.5$ & - & Taste effect, mucous membrane and water supply system \\
\hline TDS & 1000 & 5 & Palatability decreases and may cause gastrointestinal irritation in human \\
\hline $\mathrm{Ca}^{2+}$ & 300 & - & $\begin{array}{l}\text { Insufficiency causes a severe type of rickets, excess causes concretion in the } \\
\text { body such as kidney or bladder stones }\end{array}$ \\
\hline $\mathrm{Mg}^{2+}$ & 100 & - & Its salts are cathartic and diuretic. High conc. have laxative effect \\
\hline $\mathrm{Cl}^{-}$ & 250 & 5 & Injurious to people with heart and kidney ailment \\
\hline $\mathrm{SO}_{4}^{2-}$ & 250 & - & Causes gastrointestinal irritation \\
\hline $\mathrm{NO}_{3}^{-}$ & 50 & 20 & Methaemoglobinemia in infants \\
\hline $\mathrm{F}^{-}$ & 1.5 & 10 & Dental caries, crippling skeletal fluorosis \\
\hline
\end{tabular}

$D L$ desired limit, $M P L$ maximum permissible limit, all parameters expressed in $\mathrm{mg} / \mathrm{L}$ except $\mathrm{pH}$ 


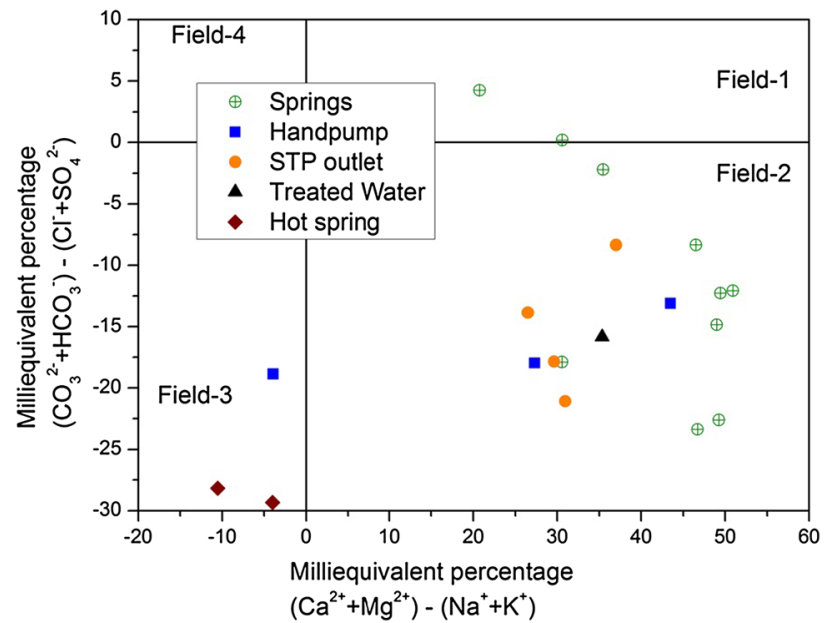

Fig. 6 Chadha's plot of water samples highlighting the dominant hydrological processes

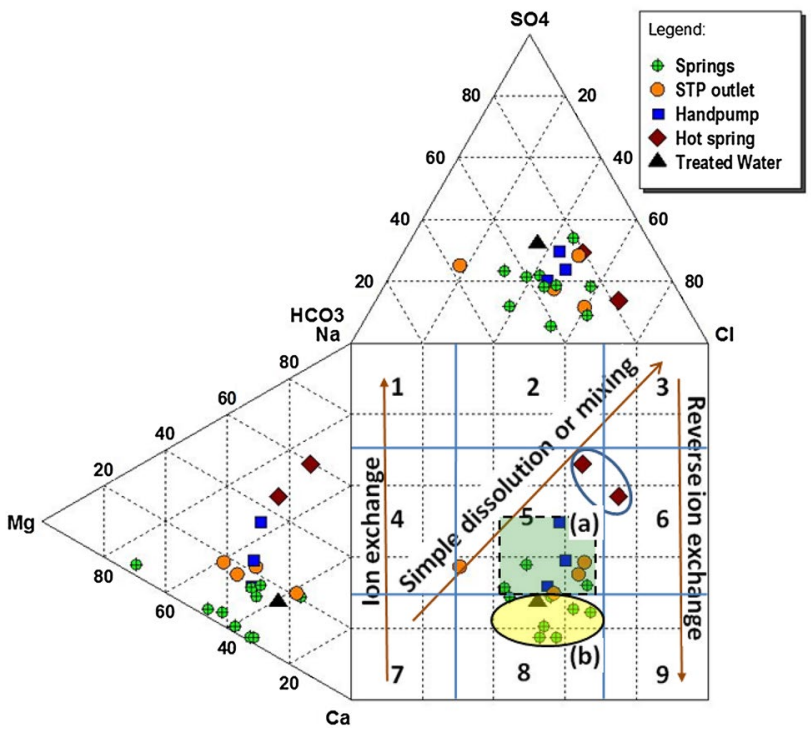

Fig. 7 Durov plot depicting hydrochemical processes involved in water samples groundwater has undergone reverse ion exchange with aquifer material. Two hot spring samples fall as a separate group fall in two different fields 5 and 6 . This could be due to mixing with cold water in different proportions. Field 6 represents water type that is not frequently encountered and indicates probable mixing or uncommon dissolution influences (Ravikumar et al. 2015).

Among different water resources, only hot springs show difference in chemical type, while rest of the water sources have more or less same chemical type. The significant different between springs close to urban sites and away is their salt content. Typical EC of the springs is $<100 \mu \mathrm{S} /$ $\mathrm{cm}$, but springs close to urban centres have slightly more EC about $200 \mu \mathrm{S} / \mathrm{cm}$ and above (T9 and T 20). Hand pump samples show hydrochemical patterns similar to that of spring water. HP located at high altitude show low TDS while HPs located near urban centre show relatively higher TDS. Only one treated water samples was collected from the study area, which shows low EC similar to spring water.

The characteristic ionic ratios were often used to interpret the rock water weathering processes (Hounslow 1995) and two ratios (in milli equivalents) viz., $\mathrm{HCO}_{3}{ }^{-} / \mathrm{Si}$ and $\mathrm{Mg}^{2+} /\left(\mathrm{Mg}^{2+}+\mathrm{Ca}^{2+}\right)$ were employed in this study. The $\mathrm{HCO}_{3}{ }^{-} / \mathrm{Si}$ ratio varies from 8.3 to 34.4 and most of the values fall above 10 . Influence of carbonate weathering is identified from ratios $>10$ while ratios $<5$ indicate silicate weathering and intermediate values (between 5 and 10) represent ambiguity. From the box plot (Fig. 8a) of $\mathrm{HCO}_{3}{ }^{-} / \mathrm{Si}$ ratio it can be observed that most of the samples fall in carbonate weathering field. To check the nature of carbonate mineral involved in water rock interaction, $\mathrm{Mg}^{2+} /\left(\mathrm{Mg}^{2+}+\mathrm{Ca}^{2+}\right)$ was calculated. The ratio of $\mathrm{Mg}^{2+} /\left(\mathrm{Mg}^{2+}+\mathrm{Ca}^{2+}\right)$ ranges from 0.20 to $0.71 . \mathrm{Mg}^{2+} /$ $\left(\mathrm{Mg}^{2+}+\mathrm{Ca}^{2+}\right)$ ratio of 0.5 represents dolomite weathering while $>0.5$ represents dolomite dissolution-calcite precipitation and $<0.5$ represents both limestone and dolomite weathering. From the box plot (Fig. 8b) of $\mathrm{Mg}^{2+} /$ $\left(\mathrm{Mg}^{2+}+\mathrm{Ca}^{2+}\right)$, it can be observed that most of the samples show ratio $<0.5$ indicating weathering of both dolomite and calcite.
Fig. 8 Box-whisker plot of a $\mathrm{HCO}_{3}{ }^{-} / \mathrm{Si}$ ratio and $\mathbf{b} \mathrm{Mg}^{2+}$ / $\left(\mathrm{Mg}^{2+}+\mathrm{Ca}^{2+}\right)$ ratio of water samples
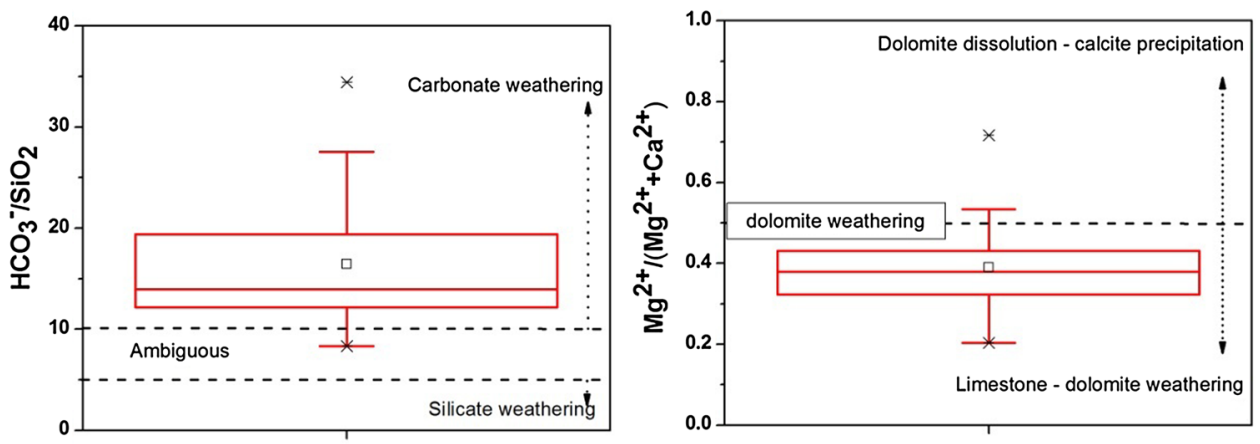


\section{Conclusion}

This main objective of this paper is to evaluate the stress on water resources based on the ex ante approach and determine the quality of the water and the possible geochemical processes impacting the water quality in Kullu valley of Himachal Himalayas. Ex-ante approach inferred rampant urbanisation, burgeoning population, climate change, high variation in rainfall pattern, change in land use pattern, presence of hydropower projects and lack of decentralised sewage treatment facilities have led to increased stress on the existing water resources in the study area. About $15 \%$ of population growth is witnessed in a decade from 2001 to 2011 which could be one of the key factors leading to the rampant urbanisation, change in land use pattern, change in microclimate and demand for more sanitation facilities. Hydrochemistry of the water samples in the study area has indicated that the current status of spring waters is satisfactory for drinking purposes with a few incidences of high $\mathrm{NO}_{3}{ }^{-}, \mathrm{F}^{-}, \mathrm{Cl}^{-}$and TDS, which are mostly attributed to contamination from sewage and geothermal activity. From both ex-ante approach and primary hydrochemical data it can be inferred that springs need to be restored in terms of both quantity and quality.

Basically two groups of waters were discerned from hydrochemical interpretation, samples that are very fresh in quality and have undergone less interaction with the aquifer material and other group of samples which have relatively higher ion content and have undergone water rock interaction and ion exchange. The hydrochemical facies, trends in diamond field of Piper's plot, Chadda's grouping and also Durov diagram have verified this hypothesis. There is no evidence with the existing data that hot springs are in hydraulic interconnection with the other cold springs and shallow groundwater (hand pump). However, to verify these findings more detailed sampling including other parameters and techniques needs to be undertaken.

\section{Future outlook}

Very low discharge rates of the springs in the valley particularly in lean period constrain the drinking water supplies in some villages and in few cases not even a single spring was functional. These villages completely rely on public water supplies and have to face hardship during summer season. Lack of decentralised sewage system at village level may further aggravate the sanitation problems and also could affect the springs if sewage wastes come in the contact with water resources. The number of the
STPs is not in proportion to the population density. Lack of decentralised solid waste and sewage disposal facilities has created an unhealthy environment in rural, urban and peri-urban areas of this valley.

Installing sewage treatment facilities at major sewage outlet points can reduce the risk of contamination of water resources particularly in downstream spring. Improvement in the spring discharges can be achieved through minimising the deforestation activities and focusing on reforestation programmes at the catchment areas. Constructing artificial rainwater harvesting structures at identified zones can also greatly help in increasing the spring discharges and sustaining the spring flows even during dry season. Future studies should focus more on the identification of recharge zones to the springs based on isotope and geomorphological techniques.

Acknowledgements The authors wish to express their thanks to Department of Science \& Technology-Promotion of University Research and Scientific Excellence, Government of India for providing the necessary financial support to carry out this study. The help rendered by Mr. Kuldeep Bist, Lab Technician, Geology Lab, Panjab University during analysis of samples has been acknowledged. The authors are also grateful to Mr. Lal Chand Thakur, Mrs. Khila Thakur and Mr. Dinesh for providing assistance during survey of the study area and sample collection.

\section{Compliance with ethical standards}

Conflict of interest On behalf of all authors, the corresponding author states that there is no conflict of interest.

Open Access This article is distributed under the terms of the Creative Commons Attribution 4.0 International License (http://creativecomm ons.org/licenses/by/4.0/), which permits unrestricted use, distribution, and reproduction in any medium, provided you give appropriate credit to the original author(s) and the source, provide a link to the Creative Commons license, and indicate if changes were made.

\section{Reference}

Al-Khashman OA (2007) Study of water quality of springs in Petra region, Jordan: a 3-year follow-up. Water Resour Manag 21(7):1145-1163

An YJ, Breindenbach GP (2005) Monitoring E. coli and total coliforms in natural spring water as related to recreational mountain areas. Environ Monit Assess 102(1-3):131-137

APHA (1998) Standard methods for the examination of water and wastewater, 19th edn. APHA, Washington

Boselli AM, Caravello GU, Baroni A (2005) The upper Mustang (Nepal) ecosystem: population, water quality and tourism. Aquat Ecosyst Health Manag 8(3):285-291

Brindha K, Rajesh R, Murugan R, Elango L (2011) Fluoride contamination in groundwater in parts of Nalgonda District, Andhra Pradesh, India. Environ Monit Assess 172(1):481-492

Brouwer R, Langford IH, Bateman IJ, Turner RK (1999) A meta-analysis of wetland contingent valuation studies. Reg Environ Change $1(1): 47-57$ 
Brown RM, McClelland NI, Deininger RA, Tozer RG (1970) Water quality index-do we dare? Water Sewage Works 117(10):339-343

Carson RT, Mitchell RC (1993) The value of clean water: the public's willingness to pay for boatable, fishable, and swimmable quality water. Water Resour Res 29(7):2445-2454

Central Ground Water Board (CGWB) (2013) Groundwater Information Booklet Kullu district Himachal Pradesh. Ministry of Water Resources, Government of India

Chadha DK (1999) A proposed new diagram for geochemical classification of natural waters and interpretation of chemical data. Hydrogeol J 7(5):431-439

Chinnasamy P, Prathapar SA (2016) Methods to investigate the hydrology of the Himalayan springs: a review, vol 169. International Water Management Institute (IWMI), p.28 (IWMIWorking Paper 169). https://doi.org/10.5337/2016.205

CPCB (2008) Guideline for water quality management. Central Pollution Control Board, Parivesh Bhawan, East Arjun Nagar, Delhi Department of Tourism (2017) Himachal Pradesh, India

Desvousges WH, Smith VK, Fisher A (1987) Option price estimates for water quality improvements: a contingent valuation study for the Monongahela River. J Environ Econ Manag 14(3):248-267

Dhar A, Sahoo S, Dey S, Sahoo M (2014) Evaluation of recharge and groundwater dynamics of a shallow alluvial aquifer in central Ganga Basin. Nat Resour Res, Kanpur (India) https://doi. org/10.1007/s11053-014-9251-y

District Disaster Management Plan (DDMP) (2011) Kullu district, Himachal Pradesh, India. http://hpkullu.nic.in/disaster/DDMP -2011.pdf

Dolma K, Rishi MS, Lata R, Herojeet R (2015) Leh district disaster management plan: a road map for sustainable and effective development. Int J Phys Soc Sci 5(7):296-304

Fan AM, Steinberg VE (1996) Health implications of nitrate and nitrite in drinking water: an update on methaemoglobinemia occurrence and reproductive and developmental toxicity. Regul Toxicol Pharmacol 23(1):35-43

Helming K, Tscherning K, König B, Sieber S, Wiggering H, Kuhlman T, Dilly O (2008) Ex ante impact assessment of land use changes in European regions - the SENSOR approach. In: Sustainability impact assessment of land use changes. Springer, Berlin, pp $77-105$

Hem JD (1991) Study and interpretation of the chemical characteristics of natural waters. Book 2254, 3rd edn. Scientific Publishers, Jodhpur, p 263

Hounslow AW (1995) Water quality data analysis and interpretation. CRC Press, Florida

IMD (2017), Customized Rainfall Information System, Hydromet Division, India Meteorological Department, Ministry Of Earth Sciences, New Delhi-110 003 . http://hydro.imd.gov.in/hydromet web/(S(zg4crj554isr0a45kijnrk45))/DistrictRaifall.aspx

Keesari T, Kulkarni UP, DeodharA Ramanjaneyulu PS, Sanjukta AK, Kumar US (2002) Geochemical characterization of groundwater from an arid region in India. Environ Earth Sci 71(11):4869-4888

Keesari T, Ramakumar KL, Chidambaram S, Pethperumal S, Thilagavathi R (2016a) Understanding the hydrochemical behaviour of groundwater and its suitability for drinking and agricultural purposes in Pondicherry area, South India-a step towards sustainable development. Groundw Sustain Dev 2:143-153

Keesari T, Sinha UK, Deodhar A, Krishna SH, Ansari A, Mohokar H, Dash A (2016b) High fluoride in groundwater of an industrialized area of Eastern India (Odisha): inferences from geochemical and isotopic investigation. Environ Earth Sci 75(14):1-17

Kumar R, Singh RD, Sharma KD (2005) Water resources of India. Curr Sci 89(5):794-811

Lee JY, Han J (2013) Evaluation of groundwater monitoring data in four megacities of Korea: implications for sustainable use. Nat Resour Res 22:103-121
Lloyd JW, Heathcoat JA (1985) Natural inorganic chemistry in relation to groundwater. Clarendon Press, Oxford

McCarthy MF (2014) Should we restrict chloride rather than sodium? Med Hypotheses 63(1):138-148

Mishra PR, Nadda RK (2014) Water Resource Pollution and Impacts on the local livelihood: a case study of Beas River in Kullu District, India. Futur Food J Food Agric Soc 2(1):61-75

Nair HC, Padmalal D, Joseph A (2015) Hydrochemical assessment of tropical springs-a case study from SW India. Environ Monit Assess 187(2):48

Nandy S, Singh C, Das KK, Kingma NC, Kushwaha SPS (2015) Environmental vulnerability assessment of eco-development zone of Great Himalayan National Park, Himachal Pradesh, India. Ecol Indic 57:182-195

Pant CC, Rawat PK (2015) Declining changes in spring hydrology of non-glacial river basins in Himalaya: a case study of Dabka catchment. In: Rajesh J (ed) Dynamics of climate change and water resources of Northwestern Himalaya. Springer, Cham pp $151-179$

Prasad AS, Pandey BW, Leimgruber W, Kunwar RM (2016) Mountain hazard susceptibility and livelihood security in the upper catchment area of the river Beas, Kullu Valley, Himachal Pradesh, India. Geoenviron Disasters 3(1):3

Rachna Bhatti (2016) Ground Water Year Book Himachal Pradesh (2014-2015) Northern Himalayan Region Dharamshala (H.P)

Ravikumar P, Somashekar RK, Prakash KL (2015) A comparative study on usage of Durov and Piper diagrams to interpret hydrochemical processes in groundwater from SRLIS river basin, Karnataka, India. Elixir Earth Sci 80(2015):31073-31077

Ravindranath NH, Rao S, Sharma N, Nair M, Gopalakrishnan R, Rao AS, Krishna N (2011) Climate change vulnerability profiles for North East India. Curr Sci 384-394

Ray SK, Ghosh S, Nagchaudhuri J, Tiwari IC, Kaur P (1981) Prevalence of fluorosis in a rural community near varanasi. Fluoride 14(2):86-90

Rowden RD, Liu H, Libra RD (2001) Results from the Big Spring basin water quality monitoring and demonstration projects, Iowa, USA. Hydrogeol J 9(5):487-497

Sah MP, Mazari RK (1998) Anthropogenically accelerated mass movement, Kullu Valley, Himachal Pradesh, India. Geomorphology 26(1):123-138

Sah MP, Mazari RK (2007) An overview of the geoenvironmental status of the Kullu Valley, Himachal Pradesh, India. J Mt Sci 4(1):003-023

Schltz SD, Lindsay BE (1990) The willingness to pay for groundwater protection. Water Resour Res 26(9):1869-1875

Sharma DA, Rishi MS, Keesari T (2016) Evaluation of groundwater quality and suitability for irrigation and drinking purposes in southwest Punjab, India using hydrochemical approach. Appl Water Sci 1-14. https://doi.org/10.1007/s13201-016-0456-6

Sharma DA, Rishi MS, Keesari T, Pant D, Singh R, Thakur N, Sinha UK (2017) Distribution of uranium in groundwaters of Bathinda and Mansa districts of Punjab, India: inferences from an isotope hydrochemical study. J Radioanal Nucl Chem 1-9. https://doi. org/10.1007/s10967-017-5288-9

Shivanna K, Tirumalesh K, Noble J, Joseph TB, Singh G, Joshi AP, Khati VS (2008) Isotope techniques to identify recharge areas of springs for rainwater harvesting in the mountainous region of Gaucher area, Chamoli District, Uttarakhand. Curr Sci 94(8):1003-1011

Singh P, Kumar N (1997) Effect of orography on precipitation in the western Himalayan region. J Hydrol 1997(1-2):183-206

Singh RB, Roy SS (2002) Climate variability and hydrological extremes in a Himalayan catchment. In: ERB and Northern European FRIEND Project 5 Conference, Slovakia 
Singh SP, Singh V, Skutsch M (2010) Rapid warming in the Himalayas: ecosystem responses and development options. Clim Dev 2(3):221-232

Singh S, Negi RS, Dhanai R (2014) A study of physico-chemical parameters of springs around Srinagar Garhwal valley, Uttarakhand. Int J Eng Dev Res 2(4)

Statistical Abstract of Kullu (2014) Himachal Pradesh, India, p 129. (http://admis.hp.nic.in/himachal/economics/REPORTS/KulluAbs tract_2014_15.pdf). Accessed 18 Jan 2018

Tambe S, Arrawatia ML, Bhutia NT, Swaroop B (2011) Rapid, costeffective and high resolution assessment of climate-related vulnerability of rural communities of Sikkim Himalaya, India. Curr Sci 101(2):165-173

Thilagavathi R, Chidambaram S, Prasanna MV, Thivya C, Singaraja C (2012) A study on groundwater geochemistry and water quality in layered aquifers system of Pondicherry region, southeast India. 2(4):253-269

Tiwari PC (2000) Land-use changes in Himalaya and their impact on the plains ecosystem: need for sustainable land use. Land Use Policy 17(2):101-111

Tripathi SD, Aravindakshan PK, Ayyappan S, Jena JK, Muduli HK, Chandra S, Pani KCI (2000) New high in carp production in India through intensive polyculture. J Aquac Tropics 15(2):119-128
Valdiya KS Bartarya SK (1991) Hydrogeological studies of springs in the catchment of the Gaula river, Kumaun Lesser Himalaya, India. Mt Res Dev 11(3):239-258

Vijay R, Kushwaha VK, Chaudhury AS, Naik K, Gupta I, Kumar R, Wate SR (2016) Assessment of tourism impact on land use/land cover and natural slope in Manali, India: a geospatial analysis. Environ Earth Sci 75(1):20

Vishwa CB, Kaur BK, Simrit K (2013) Land use/cover change and its implications for Kullu district of Himachal Pradesh, India. Int J Geomat Geosci 3(3):538-551

WHO (2011) Guidelines for drinking water quality. World Health Organization, Geneva

Publisher's Note Springer Nature remains neutral with regard to jurisdictional claims in published maps and institutional affiliations. 